\title{
PENINGKATAN KESEHATAN PERIODONTAL IBU HAMIL DALAM UPAYA MENGURANGI RESIKO BAYI DENGAN BERAT BADAN LAHIR RENDAH
}

\section{PERIODONTAL HEALTH IMPROVEMENT ON PREGNANCY TO REDUCE LOW-BIRTH-WEIGHT INFANTS RISK}

\author{
I Komang Evan Wijaksana ${ }^{1}$, Lambang Bargowo ${ }^{2}$, Shafira Kurnia Supandi ${ }^{3}$ \\ ${ }^{1,2,3}$ Departemen Periodonsia, Fakultas Kedokteran Gigi Universitas Airlangga, Surabaya \\ email: i.komang.evan.w@fkg.unair.ac.id
}

\begin{abstract}
During the Covid-19 pandemic, there was an increase in pregnancy rates in East Java. Besides efforts to suppress pregnancy rates, it is also necessary to ensure the health of the mother and fetus in order to be born healthy. The prevalence of periodontal diseases in pregnant women is high, while the dental visit of pregnant women is low. Periodontal disease is one of the risk factors of preterm birth as well as low-birth-weight (LBW) infants. In this community service, socialization held through lecture methods, QnA, discussion and self-practice procedures to maintain oral health procedures. The goal is to improve pregnant women's knowledge of the importance of dental and oral care, especially periodontal tissue during pregnancy and enhance skills of pregnant women in detecting early symptoms of periodontal diseases and to perform oral dental care independently at home. The knowledge and skills of pregnant women can be improved during this community service. By healthy periodontal tissue and teeth, it is expected that the risk of LBW infants and also preterm birth can be decreased.
\end{abstract}

Keywords: Gingivitis, LBW infants, Periodontal, Periodontitis, Pregnancy

\section{abstrak}

Selama masa pandemi Covid-19, terjadi peningkatan tingkat kehamilan di Jawa Timur. Selain usaha menekan tingkat kehamilan, perlu juga dipastikan kesehatan ibu dan janin agar lahir dengan sehat. Prevalensi kelainan periodontal pada ibu hamil tinggi sementara kunjungan ibu hamil ke dokter gigi rendah. Penyakit periodontal merupakan salah satu faktor resiko bayi lahir prematur dan juga berat badan lahir rendah (BBLR). Dalam pengabdian masyarakat ini dilakukan sosialisasi melalui metode ceramah, tanya jawab, diskusi dan praktek mandiri prosedur menjaga kesehatan rongga mulut. Tujuannya adalah meningkatkan pengetahuan ibu hamil mengenai pentingnya perawatan gigi dan mulut khususnya jaringan periodontal selama kehamilan dan meningkatnya ketrampilan ibu hamil dalam mendeteksi gejala awal kelainan periodontal dan cara melakukan perawatan gigi mulut mandiri di rumah. Pada pengabdian masyarakat ini pengetahuan dan ketrampilan ibu hamil dapat ditingkatkan. dengan jaringan periodontal dan gigi serta rongga mulut yang sehat, diharapkan resiko BBLR maupun kelahiran prematur dapat diturunkan.

Kata kunci: BBLR, Gingivitis, Hamil, Periodontal, Periodontiti

\section{PENDAHULUAN}

Kasus pertama positif Covid-19 di Indonesia diumumkan 2 Maret 2020 lalu. Penyebaran Covid-19 terjadi secara cepat keseluruh wilayah Indonesia termasuk Jawa Timur. Dampak yang ditimbulkan tidak hanya kesehatan, melainkan seluruh aspek 
kehidupan masyarakat termasuk meningkatnya tingkat kehamilan. Tingkat kehamilan di Jawa Timur dalam masa pandemi dari Februari ke Maret menunjukkan peningkatan yaitu dari 229.667 (2,84\% dari total pasangan usia subur (PUS)) pada Februari menjadi 232.287 (2,93\%) pada bulan Maret. Jumlah PUS di Jawa Timur pada data statistik rutin April 2020 tercatat sebannyak 7.849.073. Sebagian dari PUS ini tidak terlindungi/tidak memakai alat kontrasepsi (BKKBN Jatim 2020). Sementara itu, peran kader posyandu dalam promosi program keluarga berencana dan kontrasepsi pada pasangan usia subur masih terbatas (Armini dkk 2020).

Tingginya angka kehamilan dapat berimplikasi pada sosiodemografi Indonesia kedepannya. Selain upaya untuk mengurangi tingkat kehamilan, upaya untuk memastikan kehamilan yang sudah terjadi tetap dalam kondisi sehat baik bagi ibu dan janin adalah hal penting. Data Riskesdas 2018 menunjukkan proporsi gangguan/ komplikasi yang dialami selama kehamilan pada perempuan umur 10-54 tahun di Indonesia adalah sebesar $28 \%$ dan tingkat kelahiran prematur di Jawa Timur sebesar 23.3\% (Riset Kesehatan Dasar 2018). Data BPS tahun 2018 menunjukkan 885 kelahiran bayi di Surabaya dengan berat badan lahir rendah (BBLR) (BPS Jatim 2019).

Penyakit periodontal merupakan salah satu faktor resiko bayi lahir prematur dan juga BBLR (Wijaksana, 2019; Thakur $d k k$, 2020; Vidhale dkk, 2020). Studi pada 8 puskesmas di surabaya pada tahun 2019 menunjukkan prevalensi ibu hamil dengan gingivitis adalah 73\% dan periodontitis adalah 36\% (Tedjosasongko dkk 2019). Periodontitis lebih mampu mempengaruhi hasil kehamilan dibanding kebiasaan merokok maupun konsumsi alkohol saat kehamilan. Wanita dengan periodontitis generalis memiliki resiko 5 kali lebih besar mengalami kelahiran prematur sebelum usia kehamilan 35 minggu dan 7 kali lebih besar untuk mengalami kelahiran prematur dalam usia kehamilan kurang dari 32 minggu (Klokkevold dan Mealey 2019). Bayi dengan kelahiran prematur dapat memiliki berat badan lahir rendah (Meqa dkk. 2017). Penyebaran bakteri dari infeksi periodontal menuju plasenta dapat terjadi secara perhematogen melalui aliran darah. Penelitian menunjukkan bakteri P. Gingivalis mampu menembus plasenta sehingga dapat memicu peningkatan sitokin keradangan dan prostaglandin pada amnion (Daalderop dkk. 2018; Vidhale dkk. 2020).

Kecamatan Tambaksari merupakan kecamatan dengan tingkat kelahiran bayi tertinggi di Kota Surabaya berdasarkan data 2015-2019. Angka kelahiran pada kecamatan Tambak Sari pada tahun 2019 tercatat 2.492. Angka tersebut menyumbang 7,6\% kelahiran di Surabaya pada tahun 2019 (32.585), lebih tinggi dibandingkan 30 kecamatan lainnya di Surabaya (BPS Surabaya 2020). Berdasarkan data diatas, maka pengabdian masyarakat dilakukan dengan tema "Peningkatan Kesehatan Periodontal Ibu Hamil Dalam Upaya Mengurangi Resiko Bayi Dengan Berat Badan Lahir Rendah" di Klinik Utama Sahabat Medika, Kecamatan Tambak Sari.

Dalam suasana pandemi banyak praktik dokter gigi yang tidak berpraktik akibat tingginya resiko penularan Covid-19 melalui aerosol dalam prosedur perawatan rongga mulut. Melalui sosialiasi kesehatan gigi dan mulut khususnya jaringan periodontal, diharapkan terjadi peningkatan pengetahuan pentingnya perawatan gigi dan mulut khususnya jaringan periodontal bagi ilmu hamil dan peningkatan ketrampilan ibu hamil dalam mendeteksi gejala awal kelainan periodontal pada kehamilan serta peningkatan 
ketrampilan ibu hamil dalam melakukan prosedur kebersihan rongga mulut secara mandiri di rumah.

\section{METODE PENGABDIAN MASYARAKAT}

Pengabdian masyarakat dilakukan melalui 2 tahapan. Tahap pertama adalah tahap pengumpulan data awal, dilakukan melalui pengisian kuisioner oleh ibu hamil. 2 data utama yang digali adalah ada tidaknya keluhan gigi dan mulut ibu hamil selama masa kehamilan saat ini, jenis keluhan gigi dan mulut yang dirasakan serta frekuensi kontrol perawatan gigi dan mulut dalam masa kehamilannya. Data yang didapatkan digunakan sebagai acuan penyusunan materi sosialiasi.

Pada tahap kedua dilakukan sosialisasi pentingnya menjaga kesehatan gigi dan rongga mulut selama masa kehamilan. Pada tahap kedua ini setiap ibu hamil dibekali dengan buku pedoman, alat periksa mandiri kebersihan rongga mulut, dan produk kebersihan rongga mulut. Metode pelaksanaan sosialisi melalui ceramah, tanya jawab, diskusi dan praktek mandiri prosedur menjaga kesehatan rongga mulut. Indikator keberhasilan program dinilai melalui peningkatan nilai tes sebelum dan sesudah pelaksanaan sosialisasi dan dianalisa menggunakan uji komparatif 2 kelompok berpasangan dengan tingkat kepercayaan (confidence interval) 95\%. Penilaian peningkatan ketrampilan dilakukan melalui pengamatan peserta sosialisasi mampu memperagakan prosedur kebersihan rongga mulut mandiri dengan tepat.

\section{HASIL DAN PEMBAHASAN}

Pada tahap pertama, didapatkan data karakteristik ibu hamil yang melakukan pemeriksaan di lokasi pengabdian masyarakat. Mayoritas responden memiliki usia 2130 tahun, kehamilan trimester 2 dan merupakan kehamilan pertama (tabel 1).

Tabel 1. Karakteristik ibu hamil selama masa kehamilan

\begin{tabular}{|c|c|c|c|}
\hline Karakteristik & Kategori & Jumlah & Persentase \\
\hline Ibu Hamil & & 50 & 100 \\
\hline \multirow{4}{*}{ Usia } & $\leq 20$ tahun & 0 & 0 \\
\hline & 21-30 tahun & 33 & 66 \\
\hline & 31-40 tahun & 14 & 28 \\
\hline & $>40$ tahun & 3 & 6 \\
\hline \multirow{3}{*}{ Trimester Kandungan } & 1 & 6 & 12 \\
\hline & 2 & 29 & 58 \\
\hline & 3 & 15 & 30 \\
\hline \multirow{3}{*}{ Kehamilan ke- } & 1 & 26 & 52 \\
\hline & 2 & 19 & 38 \\
\hline & $\geq 3$ & 5 & 10 \\
\hline \multirow[t]{3}{*}{ Kontrol ke dokter kandungan } & 1x sebulan & 50 & 100 \\
\hline & $2 \mathrm{x}$ sebulan & 0 & 0 \\
\hline & 1x dalam 2 bulan & 0 & 0 \\
\hline
\end{tabular}


Komang Evan Wijaksana dkk.: Peningkatan Kesehatan Periodontal Ibu Hamil dalam Upaya Mengurangi Resiko Bayi dengan Berat Badan Lahir Rendah

Tabel 2. Karakteristik keluhan gigi dan rongga mulut yang dialami selama kehamilan

\begin{tabular}{|c|c|c|c|}
\hline Karakteristik & Kategori & Jumlah & Persentase \\
\hline \multirow{2}{*}{$\begin{array}{l}\text { Memiliki keluhan gigi } \\
\text { dan mulut }\end{array}$} & $\mathrm{Ya}$ & 41 & 82 \\
\hline & Tidak & 9 & 18 \\
\hline \multirow{6}{*}{ Jenis keluhan } & Gusi berdarah & 50 & 100 \\
\hline & Gusi bengkak & 34 & 64 \\
\hline & Nyeri gigi akibat berlubang & 20 & 40 \\
\hline & Gigi goyang & 8 & 16 \\
\hline & Bau mulut & 36 & 72 \\
\hline & Lainnya & 5 & 10 \\
\hline \multirow{4}{*}{$\begin{array}{l}\text { Frekuensi ke drg selama } \\
\text { kehamilan }\end{array}$} & 0 & 47 & 94 \\
\hline & 1 & 3 & 6 \\
\hline & 2 & 0 & 0 \\
\hline & $\geq 3$ & 0 & 0 \\
\hline
\end{tabular}

Data nasional menunjukkan ibu hamil di Indonesia $(95,4 \%)$ rutin melakukan pemeriksaan kandungan dan yang rutin memeriksakan kandungan minimal 4 kali selama masa kehamilannya adalah 83,5 persen (Riset Kesehatan Dasar 2013). Namun belum ada data secara nasional yang menunjukkan jumlah ibu hamil yang mendapat perawatan gigi selama masa kehamilannya. Idealnya, selama masa kehamilan, ibu hamil harus dikonsulkan ke dokter gigi untuk memeriksakan kesehatan gigi dan mulutnya. Data ini selaras dengan data awal pada pengabdian masyarakat ini, dimana ibu hamil rutin memeriksakan kandungannya setiap 1 bulan. Namun berbanding terbalik dengan perawatan gigi dan mulut, meskipun 82 persen ibu hamil memiliki keluhan terkait dengan gigi dan mulutnya, namun hanya 6 persen dari ibu hamil yang pernah memeriksakan kesehatan rongga mulutnya selama masa kehamilan ke dokter gigi (tabel 2). Gambaran ini menunjukkan pentingnya sosialisasi kesehatan gigi dan rongga mulut diberikan kepada ibu hamil.

Semua responden ibu hamil mengalami keluhan gusi berdarah selama kehamilan. Fokus ini disosialisasikan pada tahap kedua. Selain gusi berdarah, keluhan rongga mulut lain yang juga di rasakan ibu hamil adalah bau mulut (72\%), gusi bengkak (64\%), nyeri akibat gigi berlubang (40\%), gigi goyang (16\%) dan keluhan gigi mulut lainnya (5\%).

Perubahan pada gingiva selama kehamilan berhubungan dengan perubahan hormon fisiologis pada pasien wanita. Perubahan ini ditandai dengan reaksi inflamasi nonspesifik yang secara klinis mengarah pada kecenderungan perdarahan. Kehamilan mempengaruhi keparahan area gingiva yang telah beradang. Selama kehamilan, kedalaman poket, kegoyangan gigi dan cairan sulkus gingiva juga meningkat. Keparahan gingivitis meningkat selama kehamilan mulai pada bulan kedua dan ketiga kehamilan (Daalderop dkk. 2018; Vidhale dkk. 2020).

Ibu hamil dengan gingivitis kronis ringan perlu perhatian sebelum kondisi gingiva lebih parah karena area gingiva menjadi lebih besar, edematous dan kemerahan. Gusi berdarah saat menyikat gigi adalah tanda awal kelainan periodontal. Kehamilan itu sendiri tidak menyebabkan gingivitis. Perubahan hormon pada kehamilan meningkatkan 
respon keradangan pada gingiva terhadap plak, sehingga gingiva mudah mengalami radang. Oleh karena itu, ibu hamil perlu untuk memiliki ketrampilan menjaga kesehatan rongga mulut secara mandiri dengan prosedur yang benar. Ibu hamil juga perlu mengetahui tanda-tanda awal kelainan jaringan periodontal (Daalderop dkk. 2018; Vidhale dkk. 2020).

Data tahap kedua menunjukkan metode ceramah, tanya jawab, diskusi dan praktek mandiri prosedur menjaga kesehatan rongga mulut dapat meningkatkan pengetahuan ibu hamil mengenai pentingnya kesehatan gigi dan mulut selama masa kehamilan $(\mathrm{p}<0.05)$ (tabel 3). Sosialisasi di hadiri 26 ibu hamil. Dalam pengamatan langsung, ibu hamil dapat memperagakan cara mendeteksi gejala awal kelainan periodontal dan cara melakukan perawatan gigi mulut mandiri di rumah paska mengikuti sosialisasi.

Tabel 3. Hasil penilaian pengetahuan sebelum dan sesudah sosialisasi dengan uji komparasi Wilcoxon

\begin{tabular}{cccccc}
\hline Tes & Jumlah & $\begin{array}{c}\text { Median } \\
\text { (Min-Max) }\end{array}$ & X \pm SB & $\begin{array}{c}\text { Shapiro-Wilk } \\
\text { (Sig.) }\end{array}$ & $\begin{array}{c}\text { Uji } \\
\text { Wilcoxon } \\
\text { (Sig.) }\end{array}$ \\
\hline $\begin{array}{c}\text { Sebelum } \\
\text { sosialisasi }\end{array}$ & 26 & $\begin{array}{c}50 \\
(30-70)\end{array}$ & $50.38 \pm 9.80$ & 0.032 & 0.000 \\
\cline { 1 - 2 } Sesudah sosialisasi & 26 & $\begin{array}{c}100 \\
(80-100)\end{array}$ & $93.85 \pm 7.38$ & 0.000 & \\
\hline
\end{tabular}

Melalui pengabdian masyarakat ini, dengan pencapaian meningkatnya pengetahuan ibu hamil mengenai pentingnya perawatan gigi dan mulut khususnya jaringan periodontal selama kehamilan dan meningkatnya ketrampilan ibu hamil dalam mendeteksi gejala awal kelainan periodontal dan cara melakukan perawatan gigi mulut mandiri di rumah, diharapkan dapat menekan efek buruk dari infeksi jaringan periodontal dan rongga mulut baik pada kesehatan ibu maupun janinnya. Jaringan periodontal yang sehat dapat menurunkan resiko kelahiran bayi dengan BBLR maupun kelahiran prematur.

\section{PENUTUP}

\section{Simpulan}

Capaian kegiatan pengabdian masyarakat di Klinik Utama Sahabat Medika Surabaya dapat meningkatkan pengetahuan ibu hamil mengenai pentingnya perawatan gigi dan mulut khususnya jaringan periodontal untuk mengurangi resiko kelahiran dengan berat badan lahir rendah (BBLR) serta efek buruk lainnya dari gangguan gigi dan mulut pada ibu hamil dan calon buah hatinya. Pelatihan juga meningkatkan ketrampilan calon ibu dalam melakukan deteksi gejala awal kelainan periodontal dan perawatan gigi mulut mandiri di rumah.

\section{Saran}

Perlunya kerjasama lintas bidang antara bidan, dokter kandungan dan dokter gigi dalam perawatan ibu hamil secara menyeluruh. Bidan atau dokter kandungan diharapkan dapat menyarankan ibu hamil pada trimester II untuk melakukan kontrol rutin gigi dan mulut. 
Dokter gigi harus aktif memberikan penyuluhan akan pentingnya kesehatan jaringan periodontal, gigi dan mulut selama masa kehamilan.

\section{UCAPAN TERIMA KASIH}

Penulis mengucapkan terima kasih kepada Universitas Airlangga yang telah memberi dukungan pendanaan terhadap pengabdian ini (Keputusan Rektor Universitas Airlangga Nomor 532/UN3/2020)

\section{DAFTAR PUSTAKA}

Armini NKA, Triharini M, Nastiti AA. 2020. Pemberdayaan Kader Posyandu Dalam Promosi Keluarga Berencana Dan Kontrasepsi. Jurnal Layanan Masy (Journal Public Serv). 4(1): 109-115. doi: 10.20473/jlm.v4i1.2020.109-115

BKKBN Jatim. 2020. "Dampak Covid-19, Banyak Warga Tak Pakai Alat Kontrasepsi". Artikel BKKBN Jatim, 19 Mei.

BPS Jatim. 2019. Jumlah Bayi Lahir, Bayi Berat Badan Lahir Rendah (BBLR), dan Bergizi Kurang di Provinsi Jawa Timur Menurut Kabupaten Kota Tahun 2018.

BPS Surabaya. 2020. Kota Surabaya Dalam Angka 2020. Surabaya: CV. Azka Putra Pratama.

Daalderop LA, Wieland BV, Tomsin K, dkk. 2018. Periodontal Disease and Pregnancy Outcomes: Overview of Systematic Reviews. JDR Clin. Transl. Res. 3(1): 1027. doi: $10.1177 / 2380084417731097$

Klokkevold PR, Mealey BL. 2019. Impact of Periodontal Infection on Systemic Health. In: Newman MG, Takei HH, Klokkevold PR, Carranza FA (Eds.), Newman and Carranza's Clinical Periodontology Ed. 13th. Elsevier, Inc, Philadelphia, p. 208.

Meqa K, Dragidella F, Disha M, Sllamniku-Dalipi Z. 2017. The Association between Periodontal Disease and Preterm Low Birthweight in Kosovo. Acta Stomatol. Croat. 51(1): 333-40. doi: 10.15644/asc51/1/4

Riset Kesehatan Dasar. 2013. Badan Penelitian dan Pengembangan Kesehatan Departemen Kesehatan Republik Indonesia.

Riset Kesehatan Dasar. 2018. Badan Penelitian dan Pengembangan Kesehatan Departemen Kesehatan Republik Indonesia 2018.

Tedjosasongko U, Anggraeni F, Wen ML, Kuntari S, Puteri MM. 2019. Prevalence of Caries and Periodontal Disease Among Indonesian Pregnant Women. Pesqui. Bras. em Odontopediatria e Clinica Integr. 19: e4533. doi: 10.4034/pboci.2019.191.90 
Thakur RK, Yadav BK, Sultana R, dkk. 2020. Influence of periodontal infection as a possible risk factor for preterm low birth weight. J. Pharm. Bioallied Sci. 12(5): 613-618. doi: 10.4103/jpbs.JPBS_73_20

Vidhale P, Puri S, Bhongade ML. 2020. A relationship between maternal periodontal disease and preterm low birth weight: A cross-sectional study. Clin. Epidemiol. Glob. Heal. in press. doi:10.1016/j.cegh.2020.04.007

Wijaksana IKE. 2019. Dental Treatment Consideration in Pregnant Women. J. Kesehat. Gigi. 6(2): 118-125. doi: 10.31983/jkg.v6i2.5488 